Boston University School of Law

Scholarly Commons at Boston University School of Law

Faculty Scholarship

Summer 2018

\title{
Barack Obama's Emancipation Proclamation: An Essay in Memory of Judge Richard D. Cudahy
}

Jack M. Beermann

Boston University School of Law

Follow this and additional works at: https://scholarship.law.bu.edu/faculty_scholarship

Part of the Immigration Law Commons, and the President/Executive Department Commons

\section{Recommended Citation}

Jack M. Beermann, Barack Obama's Emancipation Proclamation: An Essay in Memory of Judge Richard D. Cudahy, in 67 DePaul Law Review 613 (2018).

Available at: https://scholarship.law.bu.edu/faculty_scholarship/593

This Article is brought to you for free and open access by Scholarly Commons at Boston University School of Law. It has been accepted for inclusion in Faculty Scholarship by an authorized administrator of Scholarly Commons at Boston University School of Law. For more information, please contact lawlessa@bu.edu. 


\title{
BARACK OBAMA'S EMANCIPATION PROCLAMATION: AN ESSAY IN MEMORY OF JUDGE RICHARD D. CUDAHY $\dagger$
}

\author{
Jack M. Beermann*
}

When Judge Richard D. Cudahy passed away in September 2015, the legal world lost a quiet judicial giant. Judge Cudahy was not flashy. His opinions rarely, if ever, contained headline-grabbing pronouncements. He confined his attention to the proper universe of the appellate judge, basing his opinions on the record before him and the decision of the tribunal whose decision was being appealed, whether it was a lower court or an administrative agency. In his quiet way, he embodied a judicial philosophy characterized by wisdom, common sense, and humanity. Judge Cudahy consistently interpreted and applied the law in light of its implications for the people involved, with special solicitude for those whose relative social powerlessness led them to look to the legal system for justice.

Judge Cudahy offered the clearest pronouncement of his judicial philosophy in an essay he wrote in honor of Justice William Brennan of the Supreme Court of the United States. ${ }^{1}$ In that essay, Judge Cudahy wrote:

[I]n the long run the judges who invoke a measure of intuition and passion are somehow more likely to benefit the powerless than the powerful. ... [P]erhaps this is merely an illustration of flawed induction from my own life experiences. But I expect there will always be groups too small, diffuse, or reviled to obtain redress for their real grievances through majoritarian processes. These groups will continue to prefer judges whose logic is informed by their sensitivity to the plight of the dispossessed and underrepresented .... This is all speculation, of course; nevertheless, it is a surmise deserving of consideration. $^{2}$

And lest this view be considered a license for lawless judging, Judge Cudahy continued:

$\dagger$ This Essay was prepared for the DePaul Law Review Symposium, And Justice For All: A Symposium In Memory of the Honorable Richard D. Cudahy, April 7, 2017.

* Professor of Law and Harry Elwood Warren Scholar, Boston University School of Law. Law clerk to Judge Cudahy, 1983-1984.

1. Richard D. Cudahy, Justice Brennan: The Heart Has its Reasons, 10 CARdozo L. Rev. 93 (1988).

2. Id. at 102 . 


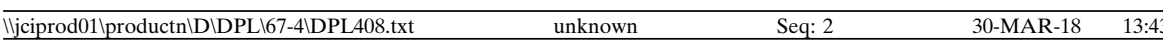

The ultimate check, however, upon the passions, intuitions and emotions of one judge is the same faculties of another judge. That is why there is appellate review. It also explains why those reviewing courts always contain more than one member. . . . In the long run Justice Brennan's approach, acknowledging passion's role in the process, enhances justice by excising the unreality, or even the hypocrisy, of an approach that purports to be grounded in pure reason. ${ }^{3}$

Most cases before the Seventh Circuit during Judge Cudahy's long tenure involved relatively simple legal and factual disputes that provided little opportunity for philosophical contemplation of the role of the decision in the grander scheme of social justice. When that rare case presented itself, Judge Cudahy's instincts and passions led him to orient the law toward protecting the powerless. In light of the attention illegal immigration is currently receiving, it is fitting to look back on an early decision of Judge Cudahy's concerning the rights of illegal immigrants under federal labor law that was affirmed by a relatively conservative Supreme Court. ${ }^{4}$

In 1976, the employees of Sure-Tan, Inc. and Surak Leather Company voted in favor of union representation. ${ }^{5}$ The employers challenged the election on the ground that six of the seven voting employees were illegal immigrants. ${ }^{6}$ In 1978, a divided panel of the Seventh Circuit upheld the bargaining order, with one judge dissenting on the ground that protecting illegal immigrants under federal labor law was inconsistent with federal immigration law. ${ }^{7}$

The bargaining order did not have its intended effect. After the National Labor Relations Board (NLRB) ordered the employers to bargain with the union, the employers informed the Immigration and Naturalization Service (INS) that the employees were in the country illegally. ${ }^{8}$ The penalties for hiring illegal workers were less harsh at the time and it was unclear whether an employer had a legal duty to inform federal authorities if it discovered that its workers were in the

3. Id. at 103-04.

4. See NLRB v. Sure-Tan, Inc., 672 F.2d 592 (7th Cir. 1982), aff'd in part and rev'd in part, 467 U.S. 883 (1984). The Supreme Court agreed with the Seventh Circuit that illegal immigrants were "employees" entitled to the protections of federal labor law. The Court disagreed, however, with the generous back pay remedy ordered by Seventh Circuit.

5. NLRB v. Sure-Tan, Inc., 583 F.2d 355, 357 (7th Cir. 1978).

6. $I d$.

7. Id. at 361 .

8. See NLRB v. Sure-Tan, Inc., 672 F.2d 592, 599 (7th Cir. 1982) aff'd in part and rev'd in part, 467 U.S. 883 (1984). 
country illegally. ${ }^{9}$ To avoid possible arrest and deportation, most of the companies' employees then left the country on their own. ${ }^{10}$

The case made its way back to the Seventh Circuit after the NLRB determined that by informing the INS that their employees were illegal immigrants the employers had constructively discharged them in retaliation for their pro-union activities in violation of the National Labor Relations Act. ${ }^{11}$ In his opinion for the court upholding the NLRB's decision, Judge Cudahy observed that illegal immigrants are often at the mercy of unscrupulous employers:

In fact, in this case as probably in others the immigration laws have provided an employer with a powerful tool for unfair and oppressive treatment of migrant labor. The immigration laws have been conveniently employed to impose the ultimate penalty of discharge (and deportation or its equivalent) if migrant laborers should have the effrontery to join a union. ${ }^{12}$

"Unfair and oppressive treatment of migrant labor," as Judge Cudahy put it in his characteristically simple yet eloquent language, remains a serious problem in the United States. ${ }^{13}$ Even putting aside the extreme cases, such as victims of human trafficking forced into illegal sex work or held as virtual slaves in legitimate service industries, there are still millions of people in the United States whose illegal status leaves them vulnerable to exploitation in the workplace. In 2012, the Obama administration announced a program designed to provide limited security to some illegal immigrants present in the United States. ${ }^{14}$ The program, entitled Deferred Action for Childhood Arrivals (DACA), included two prongs. ${ }^{15}$ First, in an exercise of traditional enforcement discretion, the administration announced that it would not seek to deport illegal immigrants who had entered the United States as minors and met other specified criteria. ${ }^{16}$ Second, immigrants who qualified for deferred action would also be eligible for documentation that would allow them to work legally during the period of deferral. ${ }^{17}$ Under the program, eligible aliens would be granted a

9. Id. at $892-93$.

a $10 . I d$. at 887 .

11. Id.

12. $I d$. at 602 .

13. Id.

14. Memorandum from Secretary of Homeland Security Janet Napolitano to Comm'r David V. Aguilar, Director Alejandro Mayorkas, and Director John Morton (June 15, 2012) (available at https://www.dhs.gov/xlibrary/assets/s1-exercising-prosecutorial-discretion-individuals-whocame-to-us-as-children.pdf).

15. Id.

16. Id.

17. Id. 
renewable deferral period of two years. ${ }^{18}$ In 2014, the Obama administration expanded DACA and initiated a new program, entitled Deferred Action for Parents of Americans (DAPA), to provide similar protections to parents of U.S. citizens or lawful permanent residents. ${ }^{19}$

These programs were attacked, often quite vociferously, largely on the ground that the President lacked the power to create them without a clear legislative basis. Much as President Harry Truman exceeded his lawful power when he ordered the Department of Commerce to seize American steel mills during the Korean War ${ }^{20}$ President Barack Obama was alleged to have exceeded his authority by creating these programs. DAPA was challenged in federal court by a group of states and state officials. In 2015, the United States District Court for the Southern District of Texas issued a preliminary injunction against the program. $^{21}$ This injunction was affirmed by the Fifth Circuit ${ }^{22}$ and by an equally divided Supreme Court in 2016.23

One of the major themes of the attacks on the deferred action programs was that President Obama took a significantly broader view of presidential power than his predecessors, such that his actions seriously intruded on the province of the legislative branch. In fact, this was a widely stated critique of President Obama, but in my view it was false. In my lifetime, there have been at least three Presidents who have been similarly accused of seriously overstepping the bounds of presidential power: Richard Nixon, Ronald Reagan, and George W. Bush. Historically, however, the President most stridently accused of tyrannical exercise of executive power was Abraham Lincoln.

It is true that President Obama was very active in some areas, most notably immigration. For several reasons, President Obama chose independent action when previous presidents might have acted with consent and even support from Congress. First, he spent most of his presidency in a divided government. Second, serious problems confronted the country during his second term, a time when many presidents become more aggressive because their power to influence Congress is greatly diminished. Gridlock increased exponentially as his presidency moved forward. But more fundamentally, from the

18. Id. at $2-3$.

19. Memorandum from Secretary of Homeland Security Jeh Charles Johnson to Comm'r R. Gil Kerlikowske, Director Leon Rodriguez, and Director Thomas S. Winkowski (Nov. 20, 2014) (available at https://www.dhs.gov/sites/default/files/publications/14_1120_memo_deferred _action.pdf).

20. Youngstown Sheet \& Tube Co. v. Sawyer, 343 U.S. 579 (1952).

21. Texas v. United States, 86 F. Supp. 3d 591 (S.D. Tex. 2015).

22. Texas v. United States, 809 F.3d 134 (5th Cir. 2015).

23. United States v. Texas, 136 S. Ct. 2271 (2016). 
outset of his presidency the opposition vowed to do everything in its power to prevent him from accomplishing anything. The opposition subjected him to unremitting criticism and accused him of tyranny every time he tried to accomplish anything. Something about President Obama provoked such extreme opposition that he had no choice but to act alone when he thought the national interest demanded some response to problems that Congress was unwilling to address. Something.

The only other President so stridently opposed from the outset was Abraham Lincoln, whose election led some Southern states to secede from the Union. One of Abraham Lincoln's most famous actions was the Emancipation Proclamation, which was viewed as one of the most tyrannical actions he took. ${ }^{24}$ The Proclamation, issued in 1862, purported to free all slaves held in the rebellious states, but not in the slave states of Delaware, Kentucky, Maryland, and Missouri that had remained in the Union. ${ }^{25}$ It also invited slaves to escape and join the Union Army, promising that the Fugitive Slave Act would not be enforced. ${ }^{26}$

There are striking parallels between Barack Obama's deferred action programs and Abraham Lincoln's Emancipation Proclamation, in terms of the problems they confronted, their aspirations, and reactions to them. This Essay is an exploration of some of those parallels and an analysis of the litigation challenging the deferred action programs on the basis that President Obama exceeded the bounds of presidential power by establishing them. The Essay means to show respect for Judge Cudahy's admonition that the law should be sensitive to "unfair or oppressive treatment" of "groups too small, diffuse, or reviled to

24. President Abraham Lincoln, Emancipation Proclamation (Jan. 1, 1863) (National Archives Identifier: 299998).

25. Id.

26. See President Abraham Lincoln, Emancipation Proclamation (Jan. 1, 1863) (National Archives Identifier: 299998) ("I do order and declare that all persons held as slaves within said designated States, and parts of States, are, and henceforward shall be free; and that the Executive government of the United States, including the military and naval authorities thereof, will recognize and maintain the freedom of said persons. ... And I further declare and make known, that such persons of suitable condition, will be received into the armed service of the United States to garrison forts, positions, stations, and other places, and to man vessels of all sorts in said service."). The British took similar actions in the Revolutionary War and the War of 1812. Slaves were urged to escape and fight on the side of the British in exchange for a promise of freedom after the war. In both cases, the British honored this promise and brought escaped slaves to freedom in England or elsewhere. Francis Scott Key referred to this in the third stanza of his poem "The Star-Spangled Banner," writing during the War of 1812 that "[n]o refuge could save the hireling and slave [f]rom the terror of flight or the gloom of the grave." 
obtain redress for their real grievances through majoritarian processes." 27

\section{Slavery and Illegal Immigration}

It might seem that any attempt to analogize slaves to illegal immigrants should fail. After all, slaves were considered the property of their masters, while illegal immigrants are generally free agents who chose to come to the United States without legal permission. For a variety of reasons, the analogy is more appropriate than might appear at first glance.

The illegal immigrants initially targeted for deferral of deportation by President Obama's first program were brought here as minors. Most came to the United States as young children in the care of their parents and had no choice or agency in the decision to emigrate. These people, referred to as dreamers, based on the DREAM Act that was proposed as a path to legal status, are just as innocent as the African children taken by slavecatchers in the seventeenth and eighteenth centuries or the babies born to slave parents in the New World.

Once in this country, illegal immigrants find themselves in circumstances similar to those faced by the slaves. Immigrants' lives are severely limited by legal restrictions on their access to education, healthcare, and government benefits of all kinds. Like slave families that could be torn apart at any time, illegal immigrants and their families are helpless to prevent the authorities from separating them through arrest, detention, and deportation. Illegal immigrants live in a constant state of insecurity, never knowing when the authorities will catch them.

Despite the DACA and DAPA programs, this insecurity was a serious problem during the Obama administration, due to the increase in immigration enforcement aimed at immigrants with criminal records. Although the numbers are disputed, ${ }^{28}$ it seems the pace of deporta-

27. Cudahy, supra note 1 , at 102 .

28. Removals were undoubtedly high during the Obama administration, but less formal immigration enforcement at the border, traditionally called "returns" were lower. See Jessica Vaughan, ICE Deportations Hit 10-Year Low, Ctr. For Immigration Studies (Jan. 2017), http://cis.org/sites/cis.org/files/jmv-enforcement-stats-1-17_0.pdf (last visited Mar. 24, 2018). Apparently, this was because fewer people crossed the border illegally during the Obama years than during previous administrations. Id. If all returns and removals are counted, the numbers under Obama appear low when compared to other recent Presidents. See id. ("[T]he number of border-crossers (and probably the number of recidivists) is much less now than was the case under the Bush and Clinton administrations, and that is probably the main reason total deportations are lower; but the Obama administration simply could explain that, rather than try to artificially manufacture a record by cherry-picking one type of deportation to count"). Vaughan characterizes returns at the border and removals pursuant to more formal process as "deportations." Id. 
tions and voluntary departures was high during the entire Obama presidency. More recently, the insecurity appears to be increasing as the Trump administration is conducting immigration raids against targets that were largely left alone under President Obama. For example, there are reports that people are being taken into detention when they apply for legal status ${ }^{29}$ and that large numbers of illegal immigrants who have not committed serious offenses have been detained under the new administration. ${ }^{30}$

The exploitation of illegal immigrants in the workplace may not be as severe as that faced by slaves, who were often worked to death, beaten, and sexually abused by their masters, but it is nevertheless a serious problem. Illegal immigrants are virtually powerless to prevent employers from violating wage and hour requirements such as minimum wage laws and overtime provisions. Employers of illegal immigrants are free to disregard rules regarding worker safety and often do not provide workers' compensation insurance, which means that illegal immigrants do not receive compensation for workplace injuries. Illegal immigrant employees cannot go to the authorities to complain about sexual harassment that is reportedly ubiquitous in some workplaces. ${ }^{31}$

The current controversy over sanctuary cities raises another parallel between slavery and illegal immigration. Sanctuary cities are cities in which officials have vowed not to enforce federal immigration laws against illegal immigrants. For example, police in sanctuary cities will not inform the federal immigration authorities if they learn that someone stopped for a minor issue, such as a traffic violation, is an illegal

Vaughan's study credits the Reagan administration with more than eight million deportations while the Washington Post, also relying on statistics from the Department of Homeland Security, reports that only 170,000 people were deported during the Reagan years. See Max Ehrenfreund, This is pretty awkward for people who criticize Donald Trump's Immigration Plans, WASH. PosT (Nov. 15, 2016), https://www.washingtonpost.com/news/wonk/wp/2016/11/15/an-inconvenienttruth-for-liberals-about-donald-trumps-deportation-plan/?utm_term=.F8712b6a3deb.

29. Maria Cramer, ICE arrested 7 people as they sought permanent status in Mass., R.I., BosтоN Globe (Feb. 21, 2018), https://www.bostonglobe.com/metro/2018/02/21/january-ice-arrested-people-they-sought-permanent-status-mass-and-rhode-island/EE4jLM6HkytwrHDUjY pdqL/story.html.

30. Andrew Khouri \& Geoffrey Mohan, ICE audits bring 'stress and anxiety', Los Angeles Times, Feb. 27, 2018, Business at 1 ("[U]nder Trump, who railed against legal and illegal immigration during the 2016 campaign and his presidency, ICE agents have become more willing to arrest anyone in the country illegally whom they encounter during enforcement actions, even if those people have no criminal convictions.").

31. See Southern Poverty Law Center, Injustice on Our Plates: Immigrant Women in the U.S. Food Industry, 41-52 (2010) (available at https://www.splcenter.org/sites/default/files/d6_legacy_ files/downloads/publication/Injustice_on_Our_Plates.pdf). 
immigrant. ${ }^{32}$ The motivation behind the sanctuary city movement is not only based on the desire to help immigrants avoid detention and deportation, although moral outrage is certainly a motivating factor. Local government officials are also concerned that if illegal immigrants do not call the police for fear of deportation they will be vulnerable to victimization by criminals. In communities with large immigrant populations this could pose a serious threat to law and order.

There was similar state and local resistance to the enforcement of federal slavery laws. Some northern cities provided sanctuary to fugitive slaves, and citizens often resisted the efforts of federal, state, and local officials to enforce federal laws that required the return of fugitive slaves. Recent reports compare today's sanctuary cities to the cooperation of citizens of Lowell, Massachusetts with the city's government to protect fugitive slaves. ${ }^{33}$ The network of safe houses and secret routes to Canada known as the Underground Railroad functioned with the knowledge and even support of some state and local authorities. Several states even passed "Personal Liberty Laws," which were ultimately held unconstitutional by the United States Supreme Court. ${ }^{34}$ These laws prohibited the state's officials from assisting in the enforcement of federal fugitive slave laws, generally nullifying the Fugitive Slave Acts in that state. ${ }^{35}$

Attorney General Jeff Sessions has threatened to withhold federal law enforcement funds from cities that refuse to enforce federal immigration laws. This threat, a milder version of that which was made during the Obama administration, reportedly led New York City to begin informing federal authorities when illegal immigrants are scheduled to appear in criminal court. ${ }^{36}$ Under well-established constitu-

32. In Boston, for example, the city's "Trust Act" prohibits police from informing federal authorities about a person's immigration status unless the federal government has a warrant for their arrest or the person has a "serious criminal history." See Travis Andersen, Boston police rebuffing ICE detainer requests, Boston Globe (Mar. 1, 2018), https://www.bostonglobe.com/ metro/2018/02/28/boston-police-rebuffing-ice-detainer-requests/IFcxjA9QIye5RXwY5NRWAJ/ story.html.

33. See, e.g., Robert Forrant, Brave Hearts: When Lowell Was a Sanctuary City-For Fugitive Slaves, wbur.org: Cognoscenti (Mar. 30, 2017), http://www.wbur.org/cognoscenti/2017/03/30/ fugitive-slave-law-lowell-sanctuary-cities-robert-forrant.

34. Ableman v. Booth, 62 U.S. 506 (1859).

35. See Joseph Tanfani \& Patrick McGreevy, "Sanctuary cities" warned to cooperate, Los ANGeles Times, April 22, 2017, at 1.

36. It is not clear if this is true. One critic, George Washington University Law Professor John Banzahf claims that it is. See John Banzahf, Following Sessions' Threat, NYC No Longer a Sanctuary City, VAluewalk (Apr. 2, 2017), http://www.valuewalk.com/2017/04/nyc-ice-sanctuary-cities-nypd/. However, the New York Times reports that New York City is not fully cooperative with federal immigration officials and, for example, did not honor a single federal detainer re- 
tional principles, state and local authorities cannot be compelled to enforce federal law. However, Congress can place conditions on the receipt of federal funds. For example, in the 1970s, most states adopted the fifty-five mile per hour speed limit in response to a federal law that would have withheld federal highway funding if they did not. ${ }^{37}$ The conditions must be voluntarily accepted by the state and local authorities. This means they must be clearly part of the federal law providing the funds (so the states are aware that by accepting the federal funds they are agreeing to the conditions), and the loss of federal funds must not be so substantial that the state and local authorities are effectively coerced into complying with the conditions. 38 Further, the federal conditions must be related to the purposes of the federal funding.

It is unclear whether the connection between federal law enforcement funds and state and local enforcement of immigration laws satisfies these conditions. Challenges to the conditions may depend on the magnitude of the withholding. If the potentially-withheld federal funds constitute a large percentage of state and local law enforcement budgets, a court might view the threat as coercive, in much the same way that the Supreme Court determined that the Affordable Care Act's threat to withhold Medicaid funding from states that refused to expand that program was unconstitutionally coercive. ${ }^{39}$

It is no answer to the sanctuary city movement to simply declare that it is unlawful for state and local governments to refuse to follow federal immigration laws or assist in their enforcement. The establishment of sanctuary cities, both during slavery and today, is a dramatic example of the difficulty presented by laws that are viewed as immoral by large segments of society. Even though every aspect of the institution of slavery was deeply immoral, the law was clearly on its side. With regard to state and local efforts to provide sanctuary to escaped slaves, the Constitution's Fugitive Slave Clause was understood to empower the federal government to enlist the aid of state and local authorities in returning escaped slaves to their masters. The Fugitive

quest in 2017. See Liz Robbins, Even in a 'Sanctuary City,' Immigrants Risk Being Deported, New York Times, Feb. 27, 2018, at A28 ("ICE issued 1,526 detainer requests to the New York Police Department in the 2017 fiscal year, up from 80 in 2016. The Police Department complied with none of them.").

37. See The Federal-Aid Highway Amendments of 1974, 23 U.S.C. $§ 154$ (1982).

38. See South Dakota v. Dole, 483 U.S. 203, 211 (1987). However, the Ninth Circuit upheld the Federal-Aid Highway Amendments of 1974 even though states not adopting the national speed limit could lose $95 \%$ of their federal highway aid. See State of Nevada v. Skinner, 884 F.2d 44 (9th Cir. 1988).

39. Nat'l Fed'n of Independent Bus. v. Sebelius, 567 U.S. 519 (2012). 
Slave Acts allowed for the seizure of alleged fugitive slaves without trial, which resulted in the enslavement of numerous free persons of African descent in the United States. ${ }^{40}$ Although slaves would have been morally justified in taking extreme measures, perhaps including homicide, to gain their freedom, the law-or local whites acting in lieu of legal process-certainly would have punished them severely.

It is also no answer to claim that the analogy between slaves and illegal immigrants does not work because slaves were owned by their masters while illegal immigrants are free. The premise does not hold. No matter what the law says, no person can ever truly own another person. The essence of humanity is the independent consciousness of each human being. It is what allowed people to survive and maintain the spark of humanity during the horrors of slavery, in the concentration camps of World War II, and in the depths of terrible poverty and deprivation. It is what allows illegal immigrants to maintain their hope and dignity in the face of the great difficulties caused by the insecurity inherent in their lack of legal status. What masters owned under the system of chattel slavery was a license, provided by their government, to treat other people as if they were property. They had an entitlement provided by the government to kidnap, imprison, and force people to labor with only the most minimal restrictions on dangerous and inhumane conditions. They had an entitlement to destroy their victims' families and social structures, deprive them of their dignity, rape them, and deny them the basic human rights recognized in all civilized societies. To a much greater degree, they had government permission to treat the enslaved the way society often treats illegal immigrants.

\section{Deferred Action Programs ${ }^{41}$}

The Departments of Justice and Homeland Security have great discretion over enforcement of immigration laws, especially when deciding who to target for detention and removal. For more than fifty years immigration authorities have formalized their discretionary enforcement decisions in programs known as "deferred action" or "tempo-

40. See, e.g., Solomon Northrup, Twelve Years a Slave (David Wilson ed., 1853).

41. Both programs described here have been rescinded by the Trump administration. The DACA program was rescinded on September 5, 2017, with a six-month grace period allowing renewal for those whose permits would expire during the six-month window. The DAPA program was rescinded on June 16, 2017. Memorandum on Rescission of DACA, 82 Fed. Reg. 43556 (Sept. 5, 2017). Due to legal challenges described below, DAPA never actually went into effect. 
rary protected status." 42 As the name implies, deferred action constitutes a discretionary decision to defer adverse action, such as deportation of a class of immigrants who meet stated criteria.

In 2012, Janet Napolitano, the Secretary of Homeland Security for the Obama administration, issued a memorandum creating a new deferred action program-DACA. ${ }^{43}$ Secretary Napolitano relied explicitly on prosecutorial discretion and established five criteria that illegal immigrants must meet to be considered for deferred action: (1) The immigrant must have come to the United States when he or she was under the age of sixteen; (2) the immigrant must have resided in the United States for at least five years and be in the United States when applying; (3) the immigrant must be in school, have graduated from school or obtained a GED, or be an honorably discharged veteran; (4) the immigrant must not have been convicted of serious criminal offenses, multiple misdemeanors, or be a threat to national security or public safety; and (5) the immigrant must be thirty years old or younger. ${ }^{44}$

The memorandum implied that even if the immigrant satisfies all of these criteria, the Department of Homeland Security retains discretion to deny deferred action; however, it was not clear when that discretion would be exercised. Successful applicants for deferred action are also eligible to apply for renewable two-year periods of work authorization during the period of deferred action. But again, there is no guarantee that all successful applicants will be granted work authorization.

In 2014, new Homeland Security Secretary Jeh Charles Johnson revamped and expanded the deferred action program in a new memorandum by including illegal immigrant parents of U.S. citizens and parents of lawful permanent residents. ${ }^{45}$ With regard to parents, the new program, known as DAPA, contains six criteria: (1) The immigrant must have a child who is a U.S. citizen or lawful permanent resident; (2) the immigrant must have continuously resided in the United States since January 1, 2010; (3) the immigrant must be physically present in the United States both on the date of the memorandum and at the time the request for deferred action is made; (4) the immigrant must not have lawful status on the date of the memorandum; (5) the

42. See generally The Department of Homeland Security's Authority to Prioritize Removal of Certain Aliens Unlawfully Present in the United States and to Defer Removal of Others, 38 Op. O.L.C. 1, 2, 3-5 (2014) (describing history of deferred action programs in immigration).

43. Memorandum from Sec'y of Homeland Sec. Janet Napolitano, supra note 14.

44. Id.

45. Memorandum from Sec'y of Homeland Sec. Jeh Charles Johnson, supra note 19. 
immigrant must not be an enforcement priority under another memorandum issued on November 20, 2014;46 (6) the immigrant must "present no other factors that, in the exercise of discretion, makes the grant of deferred action inappropriate." 47 This last criterion means that the grant of deferred action remains discretionary.

The 2014 memorandum also expanded the preexisting DACA program by removing the age cap for applicants, while retaining the requirement that the immigrant seeking deferral arrived in the United States before the age of sixteen. It also expanded eligibility by extending the cut-off date for illegal entry to January 1, 2010, and it lengthened the period of possible work authorization to three-year renewable increments.

It is perfectly understandable that the Department of Homeland Security would want to formulate and employ immigration enforcement criteria given that there are an estimated 11 to 12 million people in the country illegally. Most of the 4 million people eligible for relief under DACA and DAPA are not likely to be deported anytime soon. ${ }^{48}$ With thousands of federal employees involved in immigration enforcement, operating under stated criteria is superior to giving individual agents complete discretion. Work authorization for illegal immigrants also makes sense. We are all better off if illegal immigrants pay taxes, obtain driver's licenses and insurance, and become less likely to be victimized by unscrupulous employers who feel they can get away with paying illegal immigrants less than the minimum wage. In short, as a policy matter, the deferred action programs are a bandage on the problems caused by Congress's unwillingness to pass comprehensive immigration reform that would take a more realistic view of the consequences of having millions of people in the country illegally.

The most legally vulnerable aspect of DACA and DAPA are the provisions that allow successful applicants to be granted permission to work legally during the three-year period of deportation deferral. The Department of Homeland Security's creation of applications and issuance of permits goes well beyond what is traditionally thought of as simply exercising enforcement discretion. While there are statutes that authorize the Attorney General to grant work permission to otherwise undocumented persons deemed "lawfully present" during peri-

46. This memorandum detailed the Department's enforcement priorities, focusing primarily on criminal conduct and repeated unlawful entry and detention.

47. Id.

48. Even if the new administration steps up the pace, it is still unlikely that a significant number of those eligible for deferred action will be deported. Rather, deportations are likely to be focused on recent arrivals, people with criminal records and those who are thought to pose a threat to the security of the United States. 
ods of deferral, ${ }^{49}$ some aspects of the statutory structure indicate that this authorization is narrower than that applied by the Obama administration. Although it is not clearly illegal, it is also not clearly legal. If Congress disagrees with this aspect of deferred action, it should legislate an end to the work authorization, which it clearly could do. Because Congress has not agreed to a solution, the issue has been brought to federal courts.

\section{Why Challenges Do Not Belong In Court}

After President Obama announced the DAPA program and the expansion of DACA, suits were filed challenging the programs' legality. ${ }^{50}$ One suit, brought by notorious former-Sheriff Joseph Arpaio of Maricopa County, Arizona, was dismissed by Federal District Judge Beryl Howell for lack of standing. ${ }^{51}$ However, in another suit, brought by several states and state governors in the United States District Court for the Southern District of Texas, the court held that the State of Texas had standing because, inter alia, under state law it was required to issue driver's licenses to any person whose application under DAPA was granted by the federal government. ${ }^{52}$ On the merits, the district court issued a nationwide preliminary injunction, determining that the challengers were likely to succeed on their claim that the Administrative Procedure Act requires notice and comment before implementation of the program. The district court did not rule on the challengers' more substantive claim, that the deferred action programs violated the President's constitutional duty to "take care that the Laws be faithfully executed." 53 But the injunction based on the Administrative Procedure Act was sufficient to halt the program.

A divided Court of Appeals panel affirmed the district court's issuance of the preliminary injunction. This set the stage for Supreme Court review. At the Supreme Court, the House of Representatives filed an amicus curiae brief urging affirmance. However, after the death of Justice Antonin Scalia, with the Court's membership equally divided between Democrats and Republicans, the Fifth Circuit's decision was affirmed by an equally divided court and the case was returned to the district court for proceedings on whether to make the

\footnotetext{
49. See 8 U.S.C. $\S 1324 a(h)(3) ; 8$ C.F.R. $\S 274 a .12$ (c)(14).

50. Although the challenges were in effect to aspects of both programs, because the suits were prompted by the creation of the DAPA program, this essay will refer to DAPA litigation. These references are meant to encompass the entire breadth of the litigation.

51. See Arpaio v. Obama, 27 F. Supp. 3d 185, 190, 192 (D.D.C. 2014).

52. See Texas v. United States, 86 F. Supp. 3d 591, 617-19, 624, aff'd, 809 F.3d 134 (5th Cir. 2015).

53. U.S. Const. Art. II, § 5.
} 
preliminary injunction permanent. ${ }^{54}$ Now that the Trump administration has eliminated both DACA and DAPA the litigation challenging the programs is over, but has been replaced by several challenges to the legality of the rescission of DACA. ${ }^{55}$

Putting the merits aside, allowing challenges to be litigated in federal court goes against the weight of authority and tradition. The DAPA litigation was a political dispute between the President and the Republican Party and does not belong in federal court. Rather, it belongs in the halls of Congress. There are at least four reasons that support this conclusion.

The first problem with this litigation is standing. DAPA did not cause the plaintiffs the sort of injury traditionally required for standing to challenge government action in federal court. Texas's main claim, which was accepted by the Fifth Circuit, was that under Texas law it was required to bear the expense of issuing driver's licenses to all successful DAPA applicants. ${ }^{56}$ This is a bizarre basis for standing. It is a self-inflicted injury that could easily be remedied by Texas itself. Under the Court of Appeals' reasoning, anyone can manufacture standing to challenge government action merely by making a revocable commitment to incur an expensive obligation if the government takes the particular action. This is different from other types of voluntary action, like a decision to use a park for recreation which can give the user standing to challenge threats to the park. Texas is voluntarily doing something it claims it does not want to do; users of parks are doing something they want to do and have a right to do. The situations are completely different.

One of the interesting aspects of the DAPA litigation is the unique position of states vis-à-vis immigration law. There have been numerous conflicts between states and the federal government over immigration policy. This may be best exemplified by the Arizona state law concerning immigration enforcement that the Supreme Court held was largely preempted by exclusive federal control over immigra-

54. See United States v. Texas, 136 S. Ct. 2271, 2272 (2016).

55. Two of these cases have already reached the Supreme Court, albeit on procedural matters. In an unsigned order, the Court granted the government's petition to stay the enforcement of district court discovery orders in a challenge to the rescission of DACA brought, inter alia, by former Secretary of Homeland Security Janet Napolitano, who is now President of the University of California. See In re United States, 138 S. Ct. 371 (2017) (mem). More recently, the Court denied the government's request that it review a district court decision enjoining the elimination of DACA before the Court of Appeals had completed its review. See also Dep't of Homeland Sec. v. Regents of the Univ. of Cal., No. 17-1003, xxx S. Ct. xxx (Feb. 26, 2018).

56. See Texas, 86 F. Supp. 3d at 617-19, 624, aff'd 809 F.3d 134. 
tion. ${ }^{57}$ The Fifth Circuit supported its standing decision with a vague discussion of the special position of states, which gave up their sovereignty over certain matters when the Union under the Constitution of 1789 was formed.58 According to the Court of Appeals, because of this, states should receive "special solicitude" when a court is evaluating standing for claims challenging federal action. ${ }^{59}$ But according to the Supreme Court, the states have no legitimate role in immigration law or policy. ${ }^{60}$

In this regard, the Fifth Circuit's decision is in serious tension with the Supreme Court's jurisprudence concerning state standing. The court relied upon the Supreme Court's discussion of the issue in a case brought by the State of Massachusetts challenging the federal government's failure to regulate gases that contribute to global warming. ${ }^{61}$ But despite that decision's discussion of the special position of states, the basis for Massachusetts' standing was the rather traditional injury of erosion of state coastal property. ${ }^{62}$ Certainly, the Fifth Circuit's standing theory is contrary to the conservative position, as stated by Chief Justice Roberts in his Massachusetts v. E.P.A. dissent, that such disputes are more appropriately resolved in a political forum because the injuries alleged are too widespread and speculative to support standing. ${ }^{63}$

In fact, the standing problem presented by this litigation is a familiar one. There are many situations in which no one has standing to challenge a government decision to grant someone a benefit. For example, no one has standing to challenge an allegedly erroneous decision to grant citizenship, a green card, or a non-exclusive welfare or social security benefit to someone else. Grants of some government permits may be challenged, for example building permits may be challenged by abutters ${ }^{64}$ and permission to engage in a business may be challenged by competitors who can show injury. ${ }^{65}$ Perhaps a union representing displaced workers would have standing to challenge the

57. See Arizona v. United States, 567 U.S. 387, 416 (2012).

58. See Texas, 809 F.3d at $151-52$.

59. See id. at 151

60. See Arizona, 567 U.S. at 416.

61. Massachusetts v. EPA, 549 U.S. 497, 505 (2007).

62. Id. at 518-519.

63. Id. at 535-45 (Roberts, C.J., dissenting).

64. See 81 Spooner Road, LLC v. Zoning Bd. of Appeals of Brookline, 461 Mass. 692, 964 N.E.2d 318 (2012) (rebuttable presumption that abutter has standing to challenge zoning decision).

65. See Ass'n of Data Processing Serv. Orgs., Inc. v. Camp, 397 U.S. 150 (1970) (granting standing to competitors challenging grant of permission to banks to provide data processing services to their customers). 
grant of work authorization, but it would have to prove that union jobs were actually threatened by the newly legalized workers. However, in many cases there is simply no one with standing to take the government to court over the grant of a benefit to someone else.

Related to the standing issues for DAPA challenges, there are more general reasons why Chief Justice Roberts is correct that disputes like this do not belong in court. This was a political dispute that should have been resolved in Congress, where the states are well-represented. There is a long history of back and forth between Congress and the Executive Branch when the interpretation or application of the immigration laws is at issue. The Executive Branch has broad discretion in immigration enforcement, unless Congress has explicitly foreclosed that discretion. No law prohibited the DAPA program. It may be that the President was reading his authority under existing immigration laws too broadly, but in the immigration area when administrations have done this, Congress has passed legislation establishing explicit limits to executive power. ${ }^{66}$ If Congress disagreed with the President's exercise of discretion, it should have passed an amendment to the immigration laws or an appropriations rider to prevent execution of the DAPA program rather than simply filing a brief in the Supreme Court.

Appropriations riders are an effective means of preventing agency action with which Congress disagrees. For example, for several years Congress used appropriations riders to prevent the Clinton administration's Department of Labor from regulating ergonomic injuries to workers. ${ }^{67}$ The problem here is that the Republican majority in Congress could not come to a consensus on the appropriate reaction to the DAPA program. Perhaps Members of Congress were concerned that if they prevented DAPA, they would have harmed their party's prospects in future elections because many voters are keenly interested in immigration reform. For whatever reason, the House of Representa-

66. See Adam B. Cox \& Christina M. Rodriguez, The President and Immigration Law, 119 YAle L.J. 458, 474-76, 480, 482 (2009). The House of Representatives, in its brief Amicus Curiae in United States v. Texas presses this point as a reason to reject the DAPA and DACA programs, but the points provides support for the notion that Congress should have passed legislation against DAPA and DACA rather than filed a brief against it. See Brief for the United States House of Representatives as Amicus Curiae Supporting Respondents at 29-30, United States v. Texas, 136 S. Ct. 2271 (2016) (No. 15-674) [hereinafter Brief for the United States House of Representatives] ("[Petitioners] conveniently relegate to footnotes any mention of the many instances in which Congress has curtailed — or even eliminated - the very forms of discretion on which they rely.").

67. See Jack M. Beermann, Congressional Administration, 43 SAn Diego L. Rev. 61, 85-89 (2006) (discussion of appropriations riders generally and the rider on ergonomic injuries in particular). 
tives turned to the federal courts to do its dirty work, thereby asking the federal courts to violate principles of judicial restraint that are usually espoused by conservatives.

The third reason that this dispute did not belong in federal court relates to the characterization in the House's brief that the President was facilitating illegal conduct by millions of illegal immigrants. ${ }^{68}$ If this allegation was true, the House's remedy is explicitly provided for in the Constitution- "impeachment." 69 Any President who facilitates lawbreaking by millions of people deserves to be impeached and the members of the House who voted to submit the brief amicus curiae to the Supreme Court may have had a constitutional duty to seek impeachment. Their failure to do so leads to the question of whether they really believe what their brief stated. Perhaps they did, but they also did not want to suffer the political consequences of seeking impeachment, especially after the discord created by their failed attempt to remove President Clinton from office for lying under oath about his sex life.

The fourth reason the DAPA dispute does not belong in federal court is that there is no effective remedy that any federal court can order to prevent the administration from deferring deportation of the people who would be eligible for relief under DAPA. Under familiar principles of administrative law, again championed largely by conservatives especially the late Justice Scalia, no federal court would order an unwilling Executive Branch to deport anyone eligible for deferred status under DAPA. Any such order would require radical changes to administrative law under which the courts assume a supervisory role over the President's fulfillment of his duty to "take care that laws are faithfully executed."70 It is well understood, and argued for most vociferously by Justice Scalia, that the choice of enforcement targets is allocated by the Constitution to the President and not to Congress or the courts. ${ }^{71}$ DAPA is not so clearly illegal that it should provoke a court to take the unprecedented step of ordering the Executive Branch to deport a category of people it would prefer not to. This would be an unprecedented assertion of judicial power over Executive Branch policy. Unless a statute clearly requires agency enforcement against a particular target, any remedy that would order the Executive

68. The House's brief characterized DAPA as "authoriz[ing] more than 4 million individuals to violate those laws on a prospective basis." Brief of the United States House of Representatives, supra note 67, at 22.

69. See U.S. Const. Art. II, § 4.

70. U.S. Const. Art. II, § 5.

71. See Webster v. Doe, 486 U.S. 592, 608 (1988) (Scalia, J. dissenting). 
Branch to deport anyone would be a serious violation of basic principles of separation of powers.

In addition to these reasons supporting my conclusion that the federal courts are the wrong forum for contesting DAPA, there is a simple substantive reason why the President's view should have prevailed: the Executive Branch has discretionary power over the enforcement of the immigration laws to determine in advance that it will not deport people in certain categories. Unless Congress makes deportation mandatory for a class of people, it is well within traditional presidential discretion to choose how to deploy the limited resources allocated to enforcing the immigration laws. Additionally, there is nothing constitutionally suspect about announcing, in advance, the administration's enforcement priorities or in giving people a document certifying that they are in a non-priority category. In fact, advance notice of a categorical determination facilitates fairness and a more orderly system of administration of the laws.

Although it does not make a legal difference, discomfort with my view would be understandable if the Obama administration had basically shirked its responsibility to enforce the law. By no means was the Obama administration lax when it came to immigration enforcement, and no one expects the Trump administration to slow down either. In this era of high government debt, the Obama administration, in some years, reportedly deported more people than were deported in the entire eight years of the Reagan administration. ${ }^{72}$ Given the enormity of the Obama deportation machine, it made sense for the government to develop and announce a clear set of priorities and create a mechanism to ensure proper and humane administration of the program. As a matter of administrative law, it is usually better for the government to explicitly state and apply clear rules pertaining to the exercise of its authority than to leave it to ad hoc judgments that may lead to inconsistent and arbitrary application.

72. See FY 2016 ICE Immigration Removals, DeP'T of Homeland SEC., https://www.ice.gov/ removal-statistics/2016 (last updated Dec. 5, 2017). A table in this report indicates that annual removals during the Obama administration ranged from about 235,000 to a high over more than 400,000 . By contrast, during the George W. Bush administration, a total of approximately 2 million people were removed, for an average of approximately 250,000. Detailed statistics on immigration enforcement dating back to 1996 are available on the Department of Homeland Security's website. See Yearbook of Immigration Statistics, U.S. Dep't of Homeland Sec., https://www.dhs.gov/immigration-statistics/yearbook (last visited Mar. 16, 2018). By one count, the total number of people deported during the Reagan administration was 170,000, although another report puts the number much higher, at above 8 million. See Ehrenfreund, supra note 28; but see Vaughan, supra note 28. 


\section{The Overblown Controversy and the Emancipation Proclamation}

In my view, the controversy over President Obama's DAPA and DACA programs was seriously overblown. The reaction seemed to relate more to the opposition's determination to oppose anything that President Obama attempted to accomplish than the merits of the particular program. There was something about President Obama that provoked opposition more extreme than to any President since Abraham Lincoln. Something.

One reason for the particularly vociferous reaction was that the programs highlighted the inability of Congress to do anything about the nation's festering immigration problems. Congress is the least popular federal government institution with approval ratings below twenty percent, and its inability to pass immigration reform certainly contributes to its poor reputation. President Obama was not shy about blaming Congress for his decision to act unilaterally, which likely did not dispose Congress to support the President's immigration policy. The focus on President Obama's illegal usurpation of Congress's legislative prerogatives may have also served to distract the public from Congress's own failings.

In the House's amicus curaie brief to the Supreme Court, one of the major themes was that President Obama's seizure of power was an unprecedented step toward Executive tyranny. ${ }^{73}$ This was a theme echoed by many politicians and commentators who opposed President Obama during his eight years in office. Our collective, but short, political memory barely recalls that similar charges were levelled against Richard Nixon when he froze wages and prices and impounded congressionally appropriated funds; Ronald Reagan when he established centralized review of administrative rulemaking and illegally sold arms to Iran to illegally fund the Contras in Nicaragua; and George W. Bush, for his exercise of the powers of the Commander-in-Chief in the War on Terror. Remember that the President thought of as perhaps the most tyrannical in our history was Abraham Lincoln. His killer famously shouted "sic semper tyrannis" ("thus with all tyrants") after shooting him. ${ }^{74}$ And what was President Lincoln's greatest offense? His issuance of the Emancipation Proclamation, which purported to free slaves held by those in rebellion against the United

73. Brief for the House of Representatives, supra note 67, at 14-15 ("The extraordinary conception of executive power that petitioners press exceeds the outermost limits of law, logic, and the Constitution.").

74. See David H. Donald, Lincoln 597 (1995). 


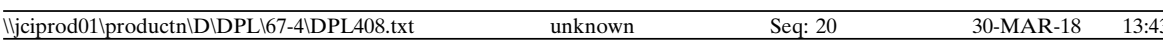

States. ${ }^{75}$ Of course, because it did not apply to any states still in the Union, that proclamation did not actually free very many slaves. That took another year of Civil War and an amendment righting one of the great constitutional wrongs in the history of the United States.

Lincoln issued the proclamation on September 22, 1862, to take effect on January 1, 1863 if the Southern states did not end their rebellion by then. ${ }^{76} \mathrm{He}$ then reissued it on January $1,1863 .{ }^{77}$ The Proclamation purported to free all slaves held in the rebellious states, not in the slave states of Delaware, Kentucky, Maryland and Missouri that had remained in the Union. ${ }^{78}$ It also invited slaves to escape and join the Union Army, and ordered the United States government to treat these slaves as free, which implicitly promised that the Fugitive Slave Law would not be enforced.

There are important parallels between the Emancipation Proclamation and President Obama's executive actions on immigration. Lincoln did not have the backing of Congress for his Proclamation. He claimed unilateral power to issue it as a war-related measure authorized by his role as Commander-in-Chief of the armed forces during the Civil War. ${ }^{79}$ The Proclamation itself freed very few slaves-only those in rebel territory that had already been taken by Union forcesand even among rebel territories some exceptions were made for areas already under firm Union control, such as areas in southern Louisiana including New Orleans. But it had tremendous symbolic impact and boosted the morale of Blacks North and South who could see emancipation on the horizon, however distant.

Similarly, President Obama did not enjoy Congress's backing when he took action to address the status of the millions of law-abiding illegal immigrants living and working in the United States. Just as President Lincoln implicitly promised not to enforce the Fugitive Slave Acts against slaves who escaped rebel territory, President Obama promised to forego enforcement of the immigration laws against a class of illegal immigrants. Both Presidents employed the power of

75. Evidence for the Unpopular Mr. Lincoln, CIVIL WAR Trust, http://www.civilwar.org/hallowed-ground-magazine/unpopular-mr-lincoln.html (last visited Feb. 10, 2018).

76. President Abraham Lincoln, Emancipation Proclamation (Jan. 1, 1863) (National Archives Identifier: 299998).

77. Id.

78. Id.

79. Donald, supra note 75, at 456-57; Lincoln stated in the Proclamation that it was issued "by virtue of the power in me vested as Commander-in-Chief, of the Army and Navy of the United States in time of actual armed rebellion against the authority and government of the United States, and as a fit and necessary war measure for suppressing said rebellion." President Abraham Lincoln, Emancipation Proclamation (Jan. 1, 1863) (National Archives Identifier: 299998). 
the federal government to extend freedom, security, dignity, and opportunity to some of the most vulnerable people in the country. Both were greeted by vehement denunciations, based largely on the view that they overstepped the bounds of their power by acting without congressional support.

One of the key parallels between the Emancipation Proclamation and Obama's deferred action program is that both claim a strong basis in morality. By 1863, there was a Northern consensus that slavery was a deeply immoral institution. The enslaved were denied any semblance of humanity. They had no control over their lives and no hope of realizing any ambitions they might develop in their degraded state. Their social and family structures were subject to destruction at the whim of their masters. Hopelessness and despair dominated their experience in the United States.

President Obama's deferred action programs are founded on a similar moral concern for illegal immigrants. People who were brought or sent to the United States as children are as blameless as the African men, women, and children who ended up here because of the slave trade. They all suffer from a similar lack of basic security and freedom to develop their human potential that was experienced by slaves and therefore cannot reach their emotional, intellectual, or economic potential. They are in constant fear of having their families ripped apart by apparently capricious decisions concerning which among the millions of illegal immigrants will be targeted for deportation.

President Obama's immigration actions also made good policy sense. Assuming that most of the people eligible for relief under DAPA or DACA are not likely to be deported, the question is whether American society is better off with them living in the shadows or allowing them to come out into the open. By and large, the answer to this question should be obvious. Allowing people to work and attend school openly is much better for all concerned, except perhaps for unscrupulous employers who would like to continue to take advantage of illegal immigrants. Just as the end of slavery should have created opportunities for other workers, less workplace exploitation should mean higher wages and better working conditions for all workers, legal and illegal. Further, there is serious concern that official hostility toward illegal immigrants makes them less likely to report criminal activity, which harms all of society.

Unlike the Emancipation Proclamation, DACA had immediate effects and DAPA would have had similar effects had the federal courts not prevented its implementation. DAPA, right now, could improve the lives of countless people who otherwise contribute positively to 
American society. It would free more people than the Emancipation Proclamation, if only the federal courts, and the House of Representatives, would leave it alone.

\section{Conclusion: The Future of Immigration Reform}

Given the decades of inaction on immigration reform, it is risky to predict a happy ending to the problem of illegal immigration in the United States. Under the current administration, an increased focus on border security is likely, whether or not the wall along the border with Mexico is built, with or without Mexican financing. The Trump administration's revocation of DACA and DAPA surprised no one. Further, some recent immigration enforcement raids indicate the new administration is targeting people who would most likely have been left alone under the prior administration. These raids include highly publicized arrests at courthouses and facilities where illegal immigrants have gone to apply for legalization.

Progress for the millions of illegal immigrants in the United States will be hard fought and may suffer serious setbacks before true progress is made. Here, again, we see a parallel with slavery. True freedom and equality did not rise out of the ashes of slavery with ease. Rather, the white establishment in the South fought hard to preserve as much of the institution as it could. Once the Reconstruction-era governments were removed from power through the terroristic activities of the $\mathrm{Ku}$ Klux Klan, the White Leagues, and others, racial oppression that rivaled actual slavery quickly developed. ${ }^{80}$ Terror as well as legal devices prevented Blacks from voting. Blacks were excluded from many professions, could not buy property or operate businesses in most locations and were, in the main, relegated to the lowest rung of the economic and social ladder. They could not freely sell their labor, but instead were relegated to sharecropping, often confined to the plantations of their former masters by a white custom of not hiring others' former slaves. Slavery was virtually replicated in the system of inmate labor, where Blacks arrested for minor offenses or trumped-up charges like vagrancy and loitering were hired out as chain gang workers. ${ }^{81}$

Under the Jim Crow system, Blacks were excluded from many social institutions and places of business. Where exclusion was impractical, although the official policy was "separate but equal," Blacks were

80. See Roger A. Fischer, The Segregation Struggle in Louisiana, 1862-77 133-57 (1974); Nicholas Lehmann, Redemption: The Last Battle of the Civil War (2006).

81. See C. Vann Woodward, The Strange Career of Jim Crow (1974). 
segregated into inferior public transportation and public accommodations. There are those who claim that even today, the Jim Crow system persists in the mass incarceration of young Black men under a war on drugs that was consciously designed to attack the Black community. ${ }^{82}$ Drug convictions have disenfranchised millions of Black voters, as part of a campaign that includes voter identification laws, to reduce liberal voting strength. ${ }^{83}$

Much the same could be said about the fate of illegal immigrants. Immigration reform has been a long time coming. In 1986, immigration reform led to amnesty for perhaps 3 million previously illegal immigrants. However, the flood of new illegal immigrants continued and shifting political winds have prevented Congress from enacting anything similar in the past three decades. DACA and DAPA may have been flashes of hope, but they are now stalled in much the same way that progress toward racial equality and dignity for the former slaves was stalled after Reconstruction. Senator Alan Simpson, one of the architects of the 1986 Immigration Act, recognized that the Act largely failed to stem the flow of illegal immigration, but he viewed it as at least a partial success: "It's not perfect, but 2.9 million people came forward. If you can bring one person out of an exploited relationship, that's good enough for me." 84 Maybe Senator Simpson exaggerates when he says freeing one person from exploitation would be enough, but 4 million is certainly a step in the right direction.

82. See Michelle Alexander, The New Jim Crow: Mass Incarceration in the Age of Colorblindedness (2012).

83. Id. at 180-82; Samuel Issacharoff, Ballot Bedlam, 64 Duke L.J. 1363 (2015).

84. See A Reagan Legacy: Amnesty For Illegal Immigrants, NPR (July 4, 2010), http:// www.npr.org/templates/story/story.php?storyId=128303672. 
